Bangladesh J. Zool. 40(1): 89-100, 2012

\title{
RICE FIELD INSECT PESTS DURING THE RICE GROWING SEASONS IN TWO AREAS OF HATHAZARI, CHITTAGONG
}

\author{
Munira Nasiruddin and Rasel Chandra Roy \\ Department of Zoology, University of Chittagong, Chittagong 4331, Bangladesh
}

\begin{abstract}
A survey of rice field insect pests was conducted during the rice growing seasons in two areas of Hathazari, Chittagong for a period of one year to prepare a preliminary list of rice field insect pests, in three rice growing seasons (Boro, Aus and Aman). During the study period 35 species belonging to 30 genera under 13 families under four economically important insect orders were recorded. These were: order Hemiptera- five families with 14 species, order Orthoptera- four families with nine species, order Lepidoptera- three families with 11 species and order- Coleoptera- one family with one species. On the basis of numerical records of the rice field insect pests, the ranking of the seasons was: Boro > Aman > Aus; of the stages was: Seedling > Transplanting > Flowering; of the orders was: Hemiptera > Orthoptera > Lepidoptera > Coleoptera; and of the spots was: Spot 2 $>$ Spot 1 .
\end{abstract}

Key words: Rice field, insect pests, rice growing seasons, abundance, incidence, Chittagong.

\section{INTRODUCTION}

Rice is a staple food for more than half of the world's population and it is grown in more than one hundred countries. Among the leading rice growing countries in the world, Bangladesh ranks fourth. Rice production in Bangladesh was less than 10 million tons in 1970, but exceeded to about 27 million tons in the years 2006-2007 (BBS 2009).

The cultivation of rice in Bangladesh varies according to seasonal changes and the availability of water supply. It is grown extensively throughout the country in overlapping seasons. There are mainly three rice growing seasons, viz. Boro (dry season rice), Aus (spring rice) and Aman (monsoon rice). The warm and humid climate of Bangladesh is conductive to the proliferation of insect pests. The three rice crops grown under diverse ecological conditions are attacked throughout the growing periods by a number of insect pests. Of the 159 species of rice insect pests recorded in Bangladesh, 20-23 species have been found to be more damaging (Alam 1977). The magnitude of damage varies in seasons, years and locations.

Insects are major constraint to rice production. Most of the rice plant parts are vulnerable to insect feeding from the time of sowing till harvesting. Both the mature and immature stages of insects injure rice plants by chewing leaf and root tissues, boring and tunneling into stems, or sucking fluid sap from stems 
and grains. The injury from feeding leads to damage showing symptoms of skeletonized and defoliated leaves, dead hearts, whiteheads, stunted and wilted plants and unfilled or pecky grains. Ultimately insect damage affects the plant physiology leading to reduction in measurable yield, utility or economic return.

As the insect pests cause damage to rice plants and are one of the reasons of total annual yield loss of rice, it is important to study the rice insect pests, especially their seasonal abundance and incidence, to evaluate the control measures. Notable works on the rice field insect pests are those of Alam (1965, 1977), Alam et al. (1981), Kamal et al. (1993), Fatema et al. (1999) and Islam et al. (2003). The entomologists of BRRI initiated systematic surveys of rice field insect pests throughout Bangladesh dividing Bangladesh into several agroecological zones and collected rice insect pests from different crops, seasons and growth stages of the rice plants (BRRI 1993, 1997, 2000, 2001, 2007, 2009).

The rice fields in Chittagong have diverse ecological conditions and presence of rice field insect pests is expected to be variable. But no attempt has been made to study the rice field insect pests in the Chittagong district. The present study was aimed to prepare a list of rice field insect pests, their abundance and incidence on different stages of rice plants and in different growing seasons.

\section{MATERIAL AND METHODS}

The rice field insect pests were collected from the paddy fields of two different spots (Jungle West Patti and Jobra) of Fatehpur Union of Hathazari Upazila of Chittagong district from December 2008 to November 2009 to determine their incidence in three rice growing seasons, i.e. Boro, Aus and Aman, and on three different stages, i.e. seedling, transplanting and flowering. The study was conducted in two different spots (Spot 1 and Spot 2) extending two $\mathrm{km}$ away from each other and three fields at each spot for each season were selected as replicates.

Growth stages of paddy plants: The entire life cycle of paddy plant was divided into three different stages, i.e. seedling, transplanting and flowering. The seedling stage started when the seeds were seeded to germinate. These took about 15 days to reach the desired size for sweeping. Usually the farmers kept the seedling stage for 30-35 days in their fields to attain a height of about 30-35 $\mathrm{cm}$. The transplanting stage began with the transplantation of paddy plants into different fields. In this stage, with the growth of plants, the maximum numbers of tiller were also formed and panicle formation began. This stage ended just before flower formation and lasted for about 50 days in the field. The flowering stage began with the formation of flower and ended just before harvesting and lasted for about 25-30 days. 
Seasonal weather factors: The duration of three stages of three rice growing seasons along with the average maximum and minimum temperature, average humidity and total rainfall recorded are tabulated below:

\begin{tabular}{|c|c|c|c|c|c|c|c|}
\hline \multirow[t]{2}{*}{ Season } & \multirow[t]{2}{*}{ Stage } & \multicolumn{2}{|c|}{ Duration of stages } & \multicolumn{2}{|c|}{$\begin{array}{c}\text { Average temp. } \\
\left({ }^{\circ} \mathrm{C}\right)\end{array}$} & \multirow{2}{*}{$\begin{array}{c}\text { Average } \\
\text { humidity } \\
(\%)\end{array}$} & \multirow{2}{*}{$\begin{array}{c}\text { Total } \\
\text { rainfall } \\
(\mathrm{mm})\end{array}$} \\
\hline & & Start & End & Max. & Min. & & \\
\hline \multirow[t]{3}{*}{ Boro } & Seedling & $\begin{array}{l}3^{\text {rd }} \text { week of } \\
\text { Dec. } 2008\end{array}$ & $\begin{array}{l}\text { Mid of Jan. } \\
2009\end{array}$ & 31.0 & 16.0 & 76 & 56 \\
\hline & Transplanting & $\begin{array}{l}1^{\text {st }} \text { week of } \\
\text { Feb. } 2009\end{array}$ & $\begin{array}{l}1^{\text {st }} \text { week of } \\
\text { April } 2009\end{array}$ & 35.3 & 11.3 & 74 & 47 \\
\hline & Flowering & $\begin{array}{l}1^{\text {st }} \text { week of } \\
\text { April } 2009\end{array}$ & $\begin{array}{l}1^{\text {st }} \text { week of } \\
\text { May } 2009\end{array}$ & 35.6 & 20.0 & 77 & 282 \\
\hline \multirow[t]{3}{*}{ Aus } & Seedling & $\begin{array}{l}1^{\text {st }} \text { week of } \\
\text { May } 2009\end{array}$ & $\begin{array}{l}1^{\text {st }} \text { week of } \\
\text { June } 2009\end{array}$ & 35.1 & 21.1 & 80 & 372 \\
\hline & Transplanting & $\begin{array}{l}2^{\text {nd }} \text { week of } \\
\text { June } 2009\end{array}$ & $\begin{array}{l}\text { 3rd week of } \\
\text { July } 2009\end{array}$ & 33.5 & 23.4 & 81 & 950 \\
\hline & Flowering & $\begin{array}{l}3^{\text {rd }} \text { week of } \\
\text { July } 2009\end{array}$ & $\begin{array}{l}2^{\text {nd }} \text { week of } \\
\text { August } 2009\end{array}$ & 33.0 & 24.0 & 85 & 1050 \\
\hline \multirow[t]{3}{*}{ Aman } & Seedling & $\begin{array}{l}\text { Mid of } \\
\text { August } 2009\end{array}$ & $\begin{array}{l}2^{\text {nd }} \text { week of } \\
\text { Sep. } 2009\end{array}$ & 33.4 & 24.6 & 86 & 950 \\
\hline & Transplanting & $\begin{array}{l}\text { Mid of Sep. } \\
2009\end{array}$ & $\begin{array}{l}\text { Last week of } \\
\text { Oct. } 2009\end{array}$ & 36.0 & 20.4 & 84 & 250 \\
\hline & Flowering & $\begin{array}{l}\text { Beginning of } \\
\text { Nov. } 2009\end{array}$ & $\begin{array}{l}\text { Last week of } \\
\text { Nov. } 2009\end{array}$ & 33.6 & 16.2 & 80 & 44 \\
\hline
\end{tabular}

Source of meterological data: Chittagong meterological office, Ambagan, Pahartoli, Chittagong.

Frequency of collection: The pests were collected on weekly basis from each field. Two types of sweeping nets were used. For the seedling stage, the diameter of the net was $16 \mathrm{~cm}$ and in both transplanting and flowering stages the diameter of the net was $23 \mathrm{~cm}$. The length of the handles of both the nets was 60 and $95 \mathrm{~cm}$, respectively. In each collection ten sweeps were made at random in the field every ten steps. All the samplings were performed between 7.30 and 8.30 a.m. For each season four samplings were performed.

Identification: Taxonomic characters were determined following Bingham (1908), Distant (1977a,b,c,d), Borror et al. (1963), Richards and Davies (1977), and Aguda et al. (1994). The collected rice field insect pests were also identified from the literature collected from BRRI and Internet sources.

Statistical analysis: Statistical comparisons were made amongst the spots, rice plant stages, rice growing seasons and the insect orders vs seasons using student's t test, ANOVA and LSD tests. 
RESULTS AND DISCUSSION

A total of 35 species of rice field insect pests belonging to 30 Genera under 13 Families within four economic insect Orders were recorded. These were: Order Hemiptera- five Families with 14 species; Order Orthoptera- four Families with nine species; Order Lepidoptera- three Families with 11 species and Order Coleptera- one Family with one species. Table 1 shows a list of the rice field insect pests recorded during the study period.

Table 1. List of the rice field insect pests recorded during the study.

\begin{tabular}{|c|c|c|c|c|}
\hline Order & Sub-order & Family & Genus & Species \\
\hline \multirow[t]{2}{*}{ Hemiptera } & Homoptera & Cicadellidae & $\begin{array}{l}\text { Nephotettix } \\
\text { Nephotettix } \\
\text { Recilia } \\
\text { Thaia } \\
\text { Tettigella } \\
\text { Sogatella } \\
\text { Nilaparvata }\end{array}$ & $\begin{array}{l}\text { nigropictus } \\
\text { virescens } \\
\text { dorsalis } \\
\text { oryzivora } \\
\text { spectra } \\
\text { furcifera } \\
\text { lugens }\end{array}$ \\
\hline & Heteroptera & $\begin{array}{l}\text { Lygaeidae } \\
\text { Pentatomidae }\end{array}$ & $\begin{array}{l}\text { Pachybrachius } \\
\text { Nezara } \\
\text { Scotinophara } \\
\text { Eysarcoris } \\
\text { Antestia } \\
\text { Leptocorisa } \\
\text { Cletus }\end{array}$ & $\begin{array}{l}\text { sp. } \\
\text { viridula } \\
\text { sp. } \\
\text { ventralis } \\
\text { degenera } \\
\text { Acuta } \\
\text { sp. }\end{array}$ \\
\hline \multirow[t]{2}{*}{ Orthoptera } & Caelifera & Acrididae & $\begin{array}{l}\text { Oxya } \\
\text { Oxya } \\
\text { Hieroglyphus } \\
\text { Hieroglyphus } \\
\text { Atractmorpha } \\
\text { Acrida }\end{array}$ & $\begin{array}{l}\text { velox } \\
\text { chinensis } \\
\text { bettoni } \\
\text { banian } \\
\text { sp. } \\
\text { exaltata }\end{array}$ \\
\hline & Ensifera & $\begin{array}{l}\text { Tetrigidae } \\
\text { Tettigoniidae } \\
\text { Gryllidae }\end{array}$ & $\begin{array}{l}\text { Paratettix } \\
\text { Conocephalus } \\
\text { Euscyrtus }\end{array}$ & $\begin{array}{l}\text { sp. } \\
\text { longipennis } \\
\text { concinnus }\end{array}$ \\
\hline Lepidoptera & Ditrysia & $\begin{array}{l}\text { Satyridae } \\
\text { Hesperiidae }\end{array}$ & $\begin{array}{l}\text { Scirpophaga } \\
\text { Scirpophaga } \\
\text { Scirpophaga } \\
\text { Nymphula } \\
\text { Cnaphalocrosis } \\
\text { Marasmia } \\
\text { Chilo } \\
\text { Paraponyx } \\
\text { Melanitis } \\
\text { Pelopidas } \\
\text { Telicota }\end{array}$ & $\begin{array}{l}\text { incertulas } \\
\text { innotata } \\
\text { auriflura } \\
\text { depunctalis } \\
\text { medinalis } \\
\text { patnalis } \\
\text { polychrysus } \\
\text { sp. } \\
\text { ismene } \\
\text { mathias } \\
\text { augias }\end{array}$ \\
\hline Coleoptera & Polyphaga & Chrysomelidae & Dicladispa & armigera \\
\hline
\end{tabular}

Incidence of pests in three stages of three seasons: The total numbers of rice field insect pests collected from two spots (Spot 1 and Spot 2) in three rice growing seasons are shown in Table 2. 
In the Boro season, 914 (22.35\%) and 936 (20.75\%) hemipteran, 309 (7.55\%) and $619(13.75 \%)$ Orthoptera, $60(1.47 \%)$ and $46(1.02 \%)$ lepidopteran and nine $(0.22 \%)$ and $13(0.28 \%)$ coleopteran pests were collected each from Spots 1 and 2 , respectively (Table 2 ).

Table 2. Number and \% of rice field insect pests collected during Boro, Aus and Aman seasons in two study spots.

\begin{tabular}{|c|c|c|c|c|c|c|c|c|c|}
\hline \multirow[t]{2}{*}{ Spot } & \multirow{2}{*}{$\begin{array}{l}\text { Season/ } \\
\text { Order }\end{array}$} & \multicolumn{3}{|c|}{ Number } & \multirow{2}{*}{$\begin{array}{l}\text { Total } \\
\text { number }\end{array}$} & \multicolumn{3}{|c|}{$\%$} & \multirow{2}{*}{$\begin{array}{l}\text { Total } \\
\text { (\%) }\end{array}$} \\
\hline & & Boro & Aus & Aman & & Boro & Aus & Aman & \\
\hline \multirow[t]{5}{*}{ Spot 1} & Hemiptera & 914 & 583 & 590 & 2087 & 22.35 & 14.26 & 14.43 & 51.06 \\
\hline & Orthoptera & 309 & 743 & 506 & 1557 & 7.55 & 18.17 & 12.35 & 38.08 \\
\hline & Lepidoptera & 60 & 113 & 249 & 422 & 1.47 & 2.76 & 6.09 & 10.32 \\
\hline & Coleoptera & 9 & 6 & 7 & 22 & 0.22 & 0.14 & 0.17 & 0.54 \\
\hline & Total & 1292 & 1445 & 1351 & 4088 & 31.60 & 35.35 & 33.05 & 100 \\
\hline \multirow[t]{5}{*}{ Spot 2} & Hemiptera & 936 & 577 & 653 & 2166 & 20.75 & 12.79 & 14.48 & 48.03 \\
\hline & Orthoptera & 619 & 669 & 660 & 1948 & 13.75 & 14.83 & 14.63 & 43.20 \\
\hline & Lepidoptera & 46 & 99 & 230 & 375 & 1.02 & 2.19 & 5.10 & 8.32 \\
\hline & Coleoptera & 13 & 3 & 4 & 20 & 0.28 & 0.06 & 0.08 & 0.45 \\
\hline & Total & 1614 & 1348 & 1547 & 4509 & 35.79 & 29.89 & 34.32 & 100 \\
\hline \multirow{5}{*}{$\begin{array}{l}\text { Spot } 1 \\
\text { and } \\
\text { Spot } 2\end{array}$} & Hemiptera & 1850 & 1160 & 1243 & 4253 & 21.50 & 13.50 & 14.46 & 49.46 \\
\hline & Orthoptera & 928 & 1412 & 1165 & 3505 & 10.80 & 16.42 & 13.56 & 40.78 \\
\hline & Lepidoptera & 106 & 212 & 479 & 797 & 1.23 & 2.46 & 5.60 & 9.29 \\
\hline & Coleoptera & 22 & 9 & 11 & 42 & 0.25 & 0.10 & 0.12 & 0.47 \\
\hline & Total & 2906 & 2793 & 2898 & 8597 & 33.78 & 32.48 & 33.74 & 100 \\
\hline
\end{tabular}

In the Aus season, $583(14.26 \%)$ and 577 (12.79\%) hemipteran, 743 $(18.17 \%)$ and $669(14.83 \%)$ orthopteran, $113(2.76 \%)$ and 99 (2.19\%) lepidopteran, and six $(0.14 \%)$ and three $(0.06 \%)$ coleopteran pests were collected each from Spots 1 and 2, respectively (Table 2).

In the Aman season, a total of 590 (14.43\%) and $653(14.48 \%)$ hemiptera, $505(12.35 \%)$ and $660(14.63 \%)$ orthopteran, 249 (6.09\%) and 230 (\%5.10\%) lepidopteran, seven $(0.17 \%)$ and four $(0.08 \%)$ coleopteran pests were collected each from Spots 1 and 2, respectively (Table 2).

The total numbers of rice the field insect pests collected in three seasons from three stages and two spots are given in Table 3. Of the total collected rice field insect pests, $739(18.07 \%), 802(19.62 \%)$ and $293(7.16 \%)$ were collected from Boro, Aus and Aman seedlings, respectively from Spots 1 and 1875 (21.80\%), $1497(17.42 \%), 749(8.71 \%)$, respectively from spot $2 ; 379(9.27 \%)$, $301(7.37 \%), 747(18.27 \%)$ were collected from Boro, Aus and Aman transplanting, respectively from Spots 1 and 700 (8.14\%), 585 (6.80\%), 1544 (17.96\%) were respectively from Spot 2; 174 (4.25\%), 342 (8.36\%), 311 (7.62\%) 
were collected, respectively from Boro, Aus and Aman flowerings of Spots 1 and 331 (3.86\%), $711(8.28 \%)$ and $605(7.03 \%)$ from Spot 2.

Table 3. Number and \% of rice field insect pests occurring in the seedling, transplanting and flowering stages of Boro, Aus and Aman seasons in the two study spots.

\begin{tabular}{|c|c|c|c|c|c|c|c|c|c|}
\hline \multirow[t]{2}{*}{ Spot } & \multirow{2}{*}{$\begin{array}{l}\text { Season/ } \\
\text { Stage }\end{array}$} & \multicolumn{3}{|c|}{ Number } & \multirow{2}{*}{$\begin{array}{l}\text { Total } \\
\text { number }\end{array}$} & \multicolumn{3}{|c|}{$\%$} & \multirow{2}{*}{$\begin{array}{l}\text { Total } \\
(\%)\end{array}$} \\
\hline & & Boro & Aus & Aman & & Boro & Aus & Aman & \\
\hline \multirow[t]{4}{*}{ Spot 1} & Seedling & 739 & 802 & 293 & 1834 & 18.07 & 19.62 & 7.16 & 44.87 \\
\hline & Transplanting & 379 & 301 & 747 & 1427 & 9.27 & 7.37 & 18.27 & 34.91 \\
\hline & Flowering & 174 & 342 & 311 & 827 & 4.25 & 8.36 & 7.62 & 20.22 \\
\hline & Total & 1292 & 1445 & 1351 & 4088 & 31.60 & 35.35 & 33.05 & 100 \\
\hline \multirow[t]{4}{*}{ Spot 2} & Seedling & 1875 & 1497 & 749 & 4124 & 21.80 & 17.42 & 8.71 & 47.93 \\
\hline & Transplanting & 700 & 585 & 1544 & 2829 & 8.14 & 6.80 & 17.96 & 32.90 \\
\hline & Flowering & 331 & 711 & 605 & 1647 & 3.86 & 8.28 & 7.03 & 19.17 \\
\hline & Total & 2906 & 2793 & 2898 & 8597 & 38.80 & 32.50 & 33.70 & 100 \\
\hline \multirow{4}{*}{$\begin{array}{l}\text { Spot } 1 \\
\text { and } \\
\text { Spot } 2\end{array}$} & Seedling & 1136 & 695 & 456 & 2287 & 25.19 & 15.41 & 10.11 & 50.72 \\
\hline & Transplanting & 321 & 284 & 797 & 1402 & 7.11 & 6.29 & 17.67 & 31.09 \\
\hline & Flowering & 157 & 369 & 294 & 820 & 3.48 & 8.18 & 6.2 & 18.89 \\
\hline & Total & 1614 & 1348 & 1547 & 4509 & 35.79 & 29.89 & 34.32 & 100 \\
\hline
\end{tabular}

The total numbers of rice field insect pests (season wise and order wise) and their respective percentages in the two spots recorded during the study period are shown in Table 2. Of the total 8597 insect pests collected the numbers of the representatives of the Order Hemiptera were 4253 (49.46\%), Orthoptera 3505 (40.78\%), Lepidoptera $479(9.29 \%)$ and Coleoptera $42(0.47 \%)$. Of the total 8597 rice field insect pests, Boro season had the highest number [2906 (33.78\%)] of total insect population followed by 2898 (33.74\%) and 2793 (32.48\%) in Aman and Aus seasons, respectively. The ranking of the Orders was: Hemiptera > Orthoptera $>$ Lepidoptera $>$ Coleoptera and that of the season was: Boro $>$ Aman $>$ Aus. The total numbers of rice field insect pests (season wise and stage wise) and their respective percentages are shown in Table 3. Of the total 8597 insect pests, seedling stage had the highest number [4121 (47.93\%)] of total insect population followed by 2829 (32.90\%) and $1647(19.17 \%)$ in the transplanting and flowering stages, respectively. Hence, the ranking of the stages were: seedling $>$ transplanting $>$ flowering stage.

Statistical analysis amongst the spots, seasons, stages and orders: The t-test done between the means of four orders of Spots 1 and 2 in three stages of three seasons showed that no significant difference existed between the means of insect orders of two spots in any of the three seasons and in any of the three stages.

ANOVA (Table 4) showed that there was no significant difference between the numbers of insect pests of three orders in three stages of the three seasons in 
Spot 1. In Spot 2 variation due to seasons was not significant, but the stages had significant effect on the orthopteran insect pest incidence. LSD showed that the difference between the means of the orthopteran pests of transplanting and flowering stages were insignificant, whereas the means of the pests of seedling and transplanting stages were significantly different from each other and similar argument was held for the means of the pests of seedling and flowering stages.

Statistical comparison (ANOVA) made between the numbers of insect pests of three insect orders of two spots with three stages in three seasons showed that the variation due to the seasons was not significant, but the orthopteran number had significant effect on stages (Table 4). LSD showed that the difference between the mean pest number of orthopteran transplant and flowering stages was not significant, but that of orthopteran seedling vs transplant and seedling vs flowering showed significant difference.

ANOVA (Table 5) done between the mean numbers of insect pests of the orders with the seasons of three stages showed that in Spot 1 in the seedling stage, there was no variation in the means of the orders and seasons. In the transplant stage variation due to orders was not significant, but in the seasons there was a significant difference. LSD showed that the difference between the mean numbers of insect pests of Boro and Aus seasons was not significant, but that of Aman and Boro, and Aman and Aus were significantly different. In Spot 2 there was again no significant difference amongst the orders and seasons of the seedling stage, but significant difference laid between the orders and seasons of the transplanting and flowering stages. In the transplanting stage variations due to order was not significant, but the seasons had significant effect on the pest incidence (Table 5). LSD showed that the difference between the mean pests of Boro and Aus was not significant, but the incidence of the representatives of the orders on Aman and Boro, and Aman and Aus was significant. However, in the flowering stage variations due to the seasons was not significant, but the number of insect pests in the orders had significant effect (Table 5). LSD showed that the difference between the mean pests of the orders Hemiptera vs Orthoptera and Orthoptera vs Lepidoptera was not significant, but significant difference laid between the numbers of insect orders Hemiptera vs Lepidoptera. Again statistical analysis done between the numbers of insect pests of the two fields and the seasons in the three stages showed no significant difference between the orders and the seedling or flowering stages, but in the transplanting stage variation due to the orders was not significant, but among the seasons were significant (Table 6). LSD showed that the difference between the mean pest number of Boro and Aus seasons were not significant, but the numbers of Aman vs Boro and Aman vs Aus seasons were significantly different. 
Insect pests are most widespread, common and persistent pests of rice. They are considered as one of the major causes of low yield in all rice growing countries including Bangladesh. During the study it was observed that hemipteran population was abundant in both the spots than the population of the other orders. Boro season had the highest number of hemipteran representatives followed by Aus and Aman seasons, but their population was highest in the seedling stage in all the seasons. Among the hemipteran pests, homopteran population had the highest infestation in the seedling stage. On the other hand, heteropteran pest population had the highest infestation in the transplanting and flowering stages. Amongst the heteropteran representatives the infestation of Pachybrachius sp. was seen in the mid transplanting stage to mid flowering stage, but their number was comparatively higher in Spot 2 than Spot 1. Higher infestation of another heteropteran pest, L. acuta was observed in late transplanting to mid flowering stages. Highest orthopteran pest infestation was observed in the seedling stage in all three seasons. Orthopteran nymph population was highest in number in the seedling stage, but with the growing of plants the nymphs became adult and in the late seedling stage a few orthopteran adults were found. The long horned grasshopper E. concinnus was observed in the late seedling stage to beginning of flowering stage. Highest infestation of adult grasshoppers was observed in late seedling stage to mid flowering stage in all seasons. Amongst the lepidopteran pests, S. incertulas was present in almost all stages and seasons. On the other hand, higher infestation of $C$. medinalis and M. patnalis was observed in mid transplanting to the late flowering stage of Aman season, but other lepidopteran species showed no remarkable appearance in all the seasons. The only coleopteran representative, $D$. armigera was present in the transplanting stage, but the infestation by this pest was very low in both the spots.

During the study period, a total of 8597 rice insect pests was collected from both the spots. Of the total 8597 insect pests, 4088 (47.55\%) and 4509 (52.44\%) were collected from Spot 1 and Spot 2, respectively. Though the number of insect pests were apparently the same, but in case of some genera and species, the variation in numbers was observed in both the spots. This situation can be the result of using insecticides, different farm practices, habitat variation or due to differences in agro-ecological spots.

Depending on the above discussion, the ranks were ordered as: Hemiptera > Orthoptera > Lepidoptera > Coleoptera; the rank of the stages according to infestation was: Seedling $>$ Transplanting > Flowering; that of the seasons was: Boro $>$ Aman $>$ Aus and of the two spots was: Spot- $2>$ Spot- 1 . 


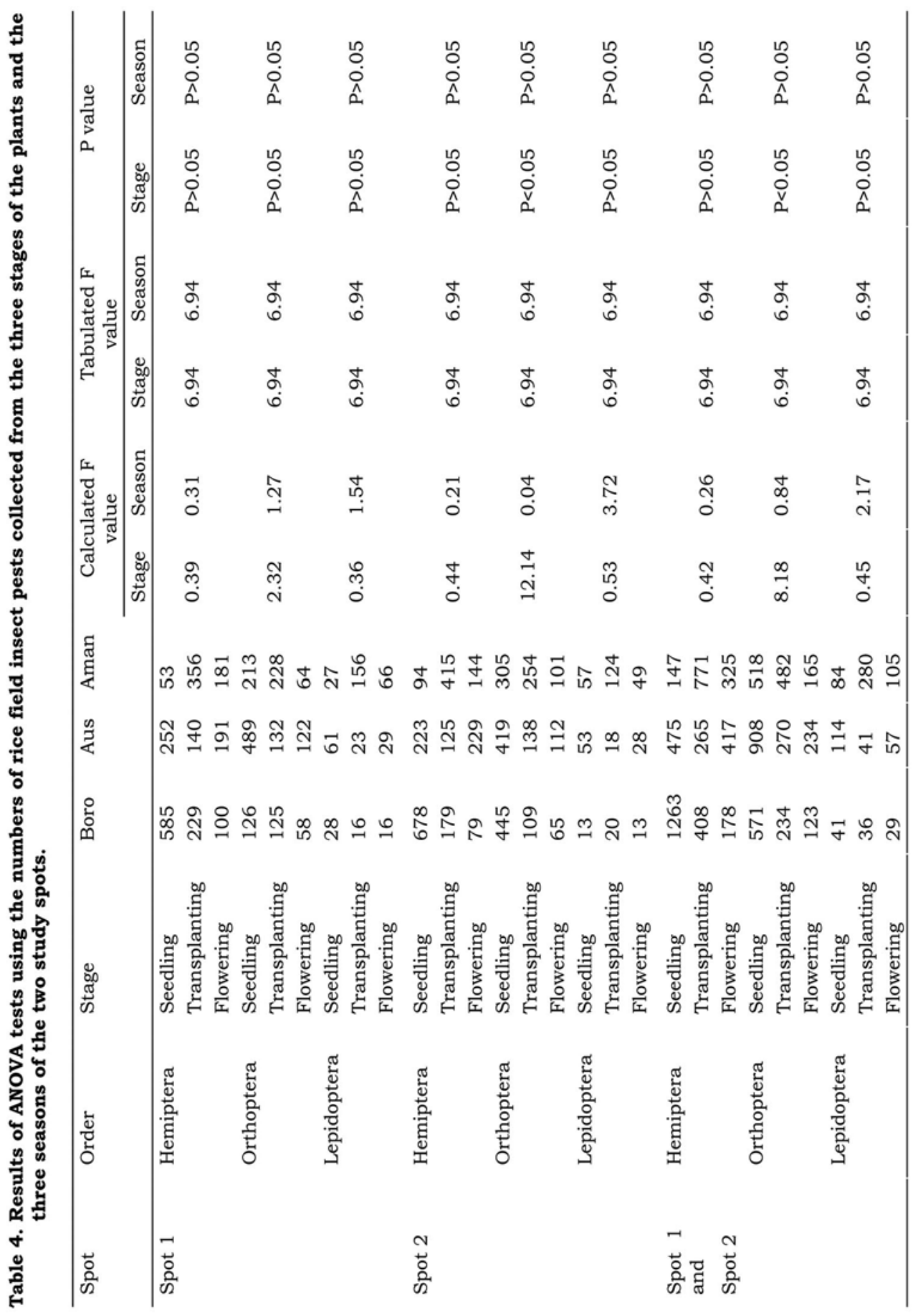




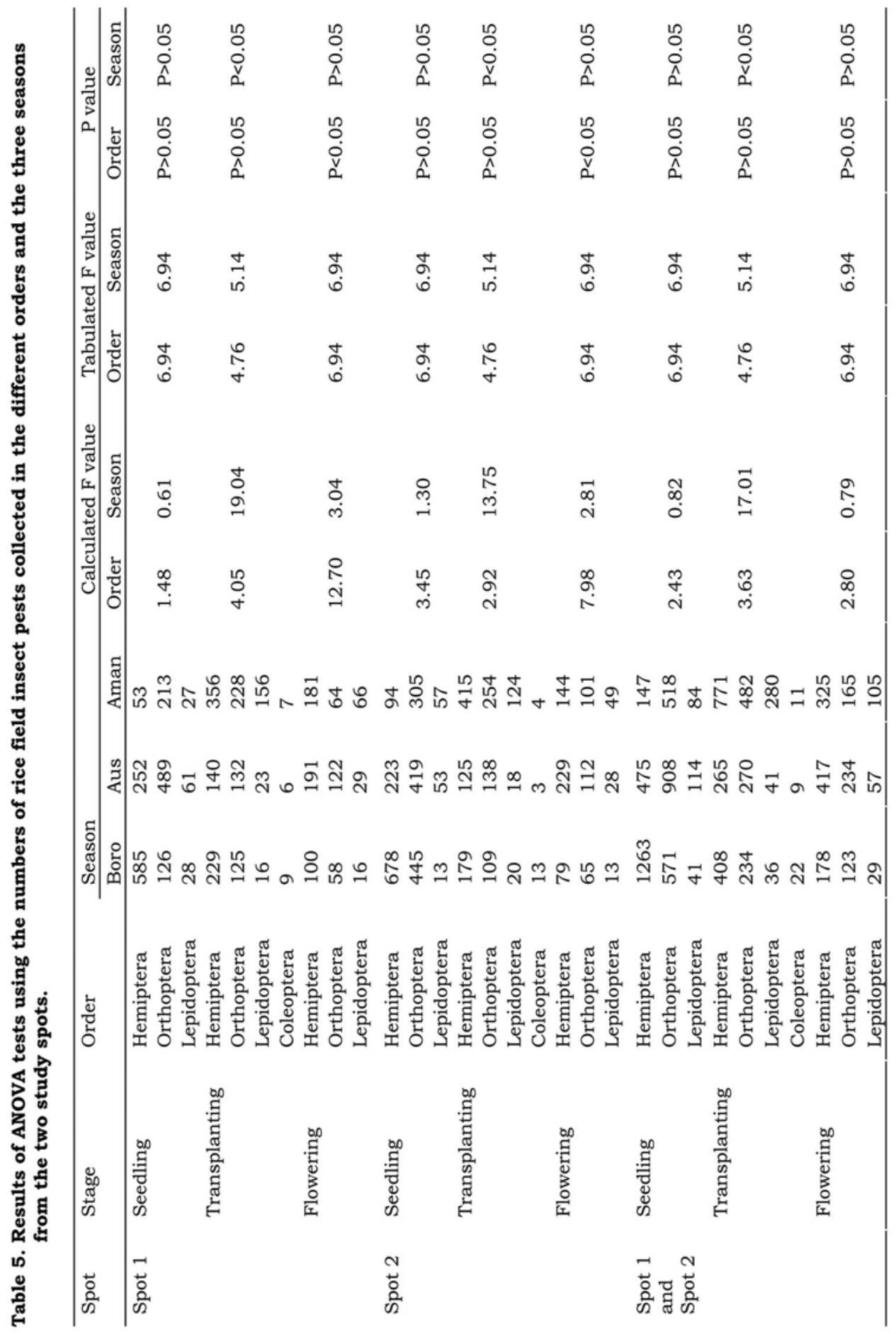


No related works on seasonal incidence of rice field insect pests were available. The reports of BRRI give some indication about the incidence of rice insect pests in different areas of the country. These reports recorded some variations in different agro-ecological zones. The pests recorded in the present study do not agree with the BRRI reports. This is because of the varying ecological condition of the areas and also on the pest outbreak which differs from year to year.

Concluding remarks: It is more than knowing that when a rice insect pest is present it should be controlled. It then requires adequate knowledge about all the factors responsible for the pest population reaching economic threshold levels. Insect rice pest population should, therefore, be assessed throughout the farm community in relation to their distribution and seasonal fluctuation under different climatic conditions.

\section{LITERATURE CITED}

AGUDA, R.M., BARRION, A.T., BHARATHI, M., CHELliAH, S., DALE, D., GALlAGHER, K.O., HEINRICHS, E.A., KIRITANI, K., LITSINGER, J.A., LOEVINSOHN, M.E., NABA, K., OOI, P.A.C., PARADA, O., ROBERTS, D.W., ROMBACH, M.C., SHEPARD, B.M., SMITH, C.M. and WEBER, G. 1994. Biology and management of rice insects. International Rice Research Institute, Los Baños, Philippines.

ALAM, M.Z. 1965. Insect Pests of Rice in East Pakistan and Their Control (Revised). Agriculture Information Service, Deptt of Agril., B.G Press, Dacca 96pp.

ALAM, S. 1977. Checklist of rice insect pests of Bangladesh. In: Literature review of insect pests and diseases of rice in Bangladesh. Director, BRRI, Gazipur-1701, Bangladesh, pp. 79-90.

ALAM, S., CATLING, H.D., KARIM, A.N.M.R., ALAM, M.S. and QURAISHI, N. 1981. Checklist of rice insects in Bangladesh. Bangladesh J. Zool. 9(2): 91-96.

BBS. 2009. Statistical year book of Bangladesh 2008. Bangladesh Bureau of Statistics, Planning division, Ministry of Planning, Government of peoples' republic of Bangladesh, Dhaka, Bangladesh.

BRRI. 1993. Annual report, Bangladesh Rice Research Institute, Gazipur 1701, Bangladesh.

BRRI. 1997. Annual report, Bangladesh Rice Research Institute, Gazipur 1701, Bangladesh.

BRRI. 2000. Annual report for July 1998-June 1999. Bangladesh Rice Research Institute, Gazipur 1701, Bangladesh.

BRRI. 2001. Annual report for July 1999-June 2000. Bangladesh Rice Research Institute, Gazipur 1701, Bangladesh.

BRRI. 2007. Annual report for July 2005-June 2006. Bangladesh Rice Research Institute, Gazipur 1701, Bangladesh.

BRRI. 2009 Proceedings of the BRRI Annual research review for 2007-2008, held on 15-18 March 2009. Gazipur, Dhaka.

BINGHAM, C.T. 1908. The Fauna of British India, including Ceylon and Burma. Rhynchota vol. IV (Homoptera). Taylor and Francis, London. 501pp.

BORROR, D.J., DELONG, D.M. and TRIPLEHORN, C.A. 1963. An Introduction to the Study of Insects. Holt Reinhart and Winston Inc. U.S.A. 819pp. 
DISTANT, W.L. 1977a. The Fauna of British India including Ceylon and Burma, Rhynchota. Vol. I (Heteroptera). Today and Tomorrow's printers and Publishers, New Delhi, India. 438pp.

DISTANT, W.L. 1977b. The Fauna of British India including Ceylon and Burma, Rhynchota. Vol.II (Heteroptera). Today and Tomorrow's printers and Publishers, New Delhi, India. 600pp.

DISTANT, W.L. 1977c. The Fauna of British India including Ceylon and Burma, Rhynchota. Vol. VI (Homoptera). Today and Tomorrow's printers and Publishers, New Delhi, India. 248pp.

DISTANT, W.L. 1977d. The Fauna of British India including Ceylon and Burma, Rhynchota. Vol.11I (Homoptera). Today and Tomorrow's printers and Publishers, New Delhi, India. 210pp.

FATEMA, A., AHMED, I., AFZAL, M., NAQVI, S.N.H. and AHMED, M. 1999. Diversity, abundance and seasonal occurrence of rice leafhopper fauna of Pakistan, Bangladesh and India. J. Bio. Sc. 7: $1-5$.

ISLAM, Z., RAHMAN, M.A., BARRIOR, A.T., POLASZEK, T., CHANCELLOR, K.L., HEONG, N., AHMED, N., HAQ, M. and KAMAL, N.Q. 2003. Diversity of arthropods in irrigated rice in Bangladesh. Bangladesh J. entomol. 13(2): 1-25.

KAMAL, N.Q., KARIM, A.N.M.R. and ALAM, S. 1993. A supplemental list of rice insect pests and their parasitoids in Bangladesh. Bangladesh J. entomol. 3(1\&2): 67-71.

RICHARDS, O.W. and DAVIES, R.G. 1977. A General Textbook of Entomology. Vol. 2. 9th edition. Chapman and Hall, London. 1354 pp.

(Manuscript received on August 23, 2011; revised on March 5, 2012) 